\title{
Pendekatan OEE (Overall Equipment Effectiveness) Untuk Mengurangi Losses Pada Mesin Moulding Cerex
}

\author{
Emi Karmilawati $^{1 *}$, Kristanto Mulyono ${ }^{2}$, Suwaryo Nugroho ${ }^{3}$ \\ 1,2,3 STT Muhammadiyah Cileungsi, Cileungsi \\ *Corresponding author: emikarmila78@gmail.com
}

\section{ARTICLE INFORMATION}

Received: 25 Januari 2021

Revised: 06 April 2021

Accepted: 26 Juli 2021

Available online: 28 September 2021

\section{KEYWORDS}

$T P M$,

$O E E$,

Moulding Cerex.

\section{INTRODUCTION}

Seiring dengan peningkatan aktiftas mesin pada proses produksi dalam industri pangan maupun manufaktur[1] lambat laun akan pemicu penurunan kinerja mesin, jika hal tersebut tidak menjadi perhatian penting[2], penurunan kinerja mesin akan berdampak pada aktivitas proses produksi serta menurunkan tingkat kualitas produk yang dihasilkan[3][4].

Untuk mencegah kerusakan pada mesin diperlukan perawatan dan pemeliharaan mesin secara berkala pada saat aktivitas proses berlangsung[5]. Dalam melakukan perawatan dan pemeliharaan pada mesin dibutuhkan metode/konsep yang tepat dalam melakukan proses perawatan dan pemeliharaan pada mesin, salah satu metode yang dapat digunakan yaitu TPM (Total Productive Maintenance).[6]

Total productive maintenance merupakan suatu program untuk mengembangkan proses pemelirahaan pada mesin di suatu manufaktur yang melibatkan seluruh sumber daya manusia. Dalam konsep TPM terdapat tools yang membantu pada proses pemeliharaan yaitu sering disebut dengan OEE (Overall Equipment Effectivenes)[7].

OEE suatu metode dalam konsep TPM yang memiliki kemampuan dalam mengetahui faktor penyebab utama yang menyebabkan kerusakan pada mesin, sehingga peneliti dapat lebih fokus dalam memperbaiki masalah yang sedang terjadi[8].

Penelitian ini dilakukan pada salah satu industri pembuat makanan ringan, yang dalam aktivitas proses produksinya kerap terjadi proses produksi terhenti yang disebabkan oleh speed losses pada mesin moulding cerex, dalam hal ini peneliti memakai konsep TPM dengan metode OEE, agar dapat mengetahui akar masalah yang menjadi penyebab speed losses pada mesin moulding cerex.

\section{METHOD}

Metode penelitian dalam langkah-langkah penelitian dapat di lihat pada gambar 1 .

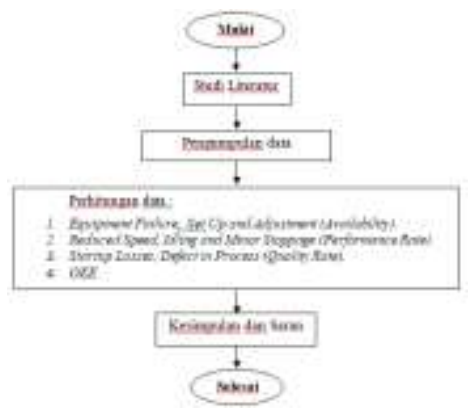

Gambar 1. Langkah-langkah Penelitian 
1. Studi Literature

Studi literature dilakukan pada penelitian ini dengan mengumpulkan buku, jurnal, dan skripsi yang relevan, yang berhubungan dengan teori TPM.

2. Pengumpulan Data

Data yang di kumpulkan dalam mendukung penelitian ini, yaitu: data proses produksi (data aktual hasil produksi \& data reject), data breakdown pada mesin dan data loading time dan data planning time

3. Perhitungan Data

a. Availability

Dalam penghitungan availability peneliti pengumpulan data waktu equipment failure, waktu set up and adjustment untuk mengetahui nilai availability pada mesin moulding cerex.

b. Perfomance Rate

Dalam perhitungan performance Rate, peneliti melakukan pengumpulan data yang terkait dengan waktu reduced speed, idling and minor stoppages, yang nantinya di olah datanya untuk mengetahui berapa besar nilai performance rate pada mesin moulding cerex.

c. Reject Rate

Dalam perhitungan reject rate peneliti melakukan pengumpulan data mengenai data waktu startup losses, dan jumlah data defect in process untuk mengetahui berapa besar nilai reject rate pada mesin moulding cerex

d. OEE

Dalam tahap penghitungan OEE peneliti akan menghitung nilai OEE dengan cara menggabungkan semua pengolahan nilai availability, performance rate dan reject rate, seperti rumus dibawah ini :

OEE = Avaiblity $(\%) x$ Performance rate $(\%) x$ Quality rate (\%) ............................ 1

\section{RESULTS AND DISCUSSION}

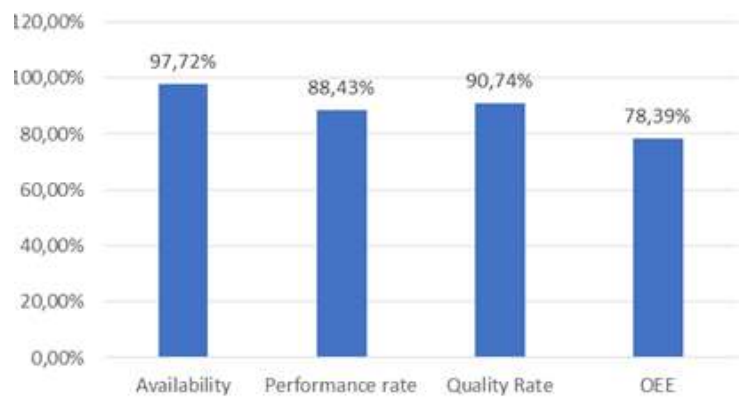

Gambar 2. Grafik Rata-rata nilai Availability, Performance Rate, Quality Rate, \& OEE

46 Emi Karmilawati
Berdasarkan pengolahan data yang telah diuraikan pada gambar 2. Terlihat jelas pada label diatas bahwa availability rata-rata total untuk tiga bulan bernilai $97.72 \%$. rata-rata nilai performance rate secara keseluruhan diatas $88.34 \%$ menunjukkan bahwa nilai performance rate perusahaan masih dibawah kondisi ideal yang seharusnya lebih besar dari $95 \%$. Nilai quality rate rata-rata sebesar $90.74 \%$, rendahnya nilai quality rate disebabkan banyaknya defect in process pada saat produksi berlangsung. Dari tiga fungsi OEE, yang memberi kontribudi nilai terendah dari nilai OEE adalah nilai performance rate yaitu sebesar $88.74 \%$.

Setelah data availability, performance rate, quality rate dan OEE didapatkan selanjutnya menghitung six big losses yang dapat dilihat pada gambar 3 .

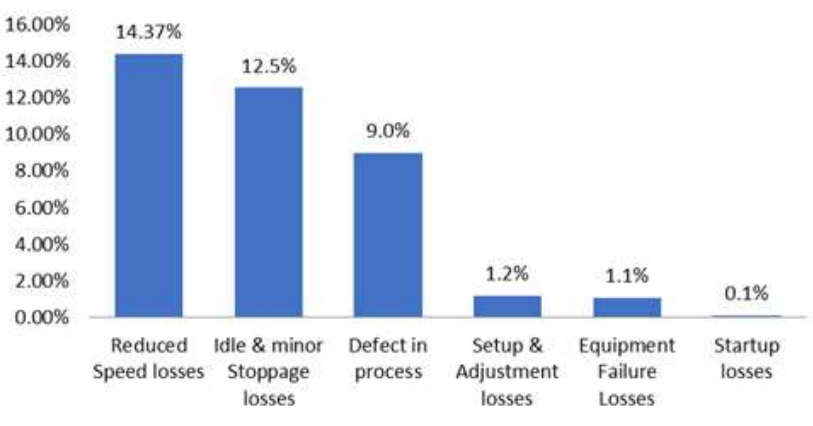

Gambar 3. Grafik pengolahan data six big losses

Dari gambar 3. Dapat dilihat hasil pengolahan data pada six big losses, nilai six big losses tertinggi pada faktor reduced speed losses yaitu 14,37\%.

Setelah melakukan penghitungan langkah selanjutnya menganalisa dengan menggunakan fishbone diagram untuk mengetahui akar masalah yang menyebabkan reduced speed losses tinggu dapat dilihat pada Gambar 4.

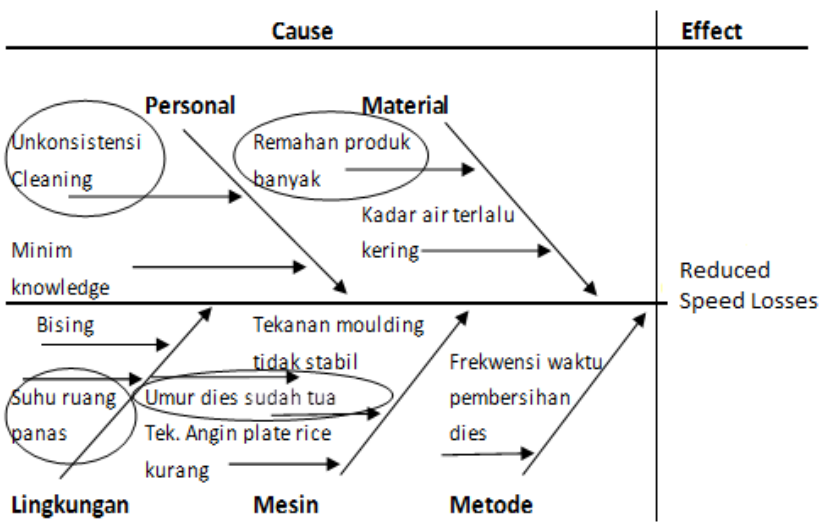

Gambar 5. Fishbone diagram reduced speed losses

Pada gambar diatas terlihat bahwa sebab akibar dari beberapa faktor yang dapat mempengaruhi kecepatan berkurang maka diketahui penyebab defect yang terbesar terjadi pada bentul black spot yang dipengaruhi oleh https://doi.org/10.30998/ joti.v3i2.8576 
tekananberkurang karena terganjal sisa-sisa kotoran yang menempel pada produk juga dipengaruhi oleh dies kotor karena sisa scrub yang menempel pada produk yang menyebabkan reduced speed losses yaitu dies kotor.

Setelah diketahui penyebab dari nilai reduced speed losses, renah kemudian dilakukan tindakkan perbaikan dalam proses prouksi yang meliputi perubahan pola kerja dan penambahan peralatan sebagai bagian dari usaha meningkatkan nilai OEE, ialah:

1. Mengaakan training kepada operator terkait standar penyetingan an proses pembersihan dies.

2. Melakukan monitoring secara berkala terhaap proses setting dies dan pembersihan dies.

3. Melengkapi mesin dengan alat cleaning automatic (Pneomatic roadless cylinder)

4. Pembersihan dies setiap satu jam sekali.

Setelah satu bulan diaplikasikan yaitu bulan februari 2018 yang dapat dilihat pada gambar 6 \& 7 .

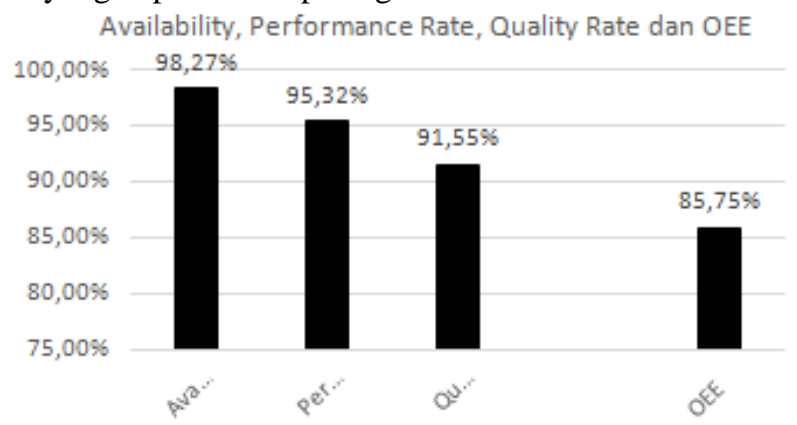

Gambar 6. Grafik persentase perbaikan availability, performance, quality rate dan $\mathrm{OEE}$

Pada gambar 6, data yang diperoleh sebelumnya antara sebelum dan sesudah perbaikan ternyata ada kenaikkan nilai OEE yang cukup baik dari sebelumnya $78.14 \%$ menjadi $85.75 \%$.

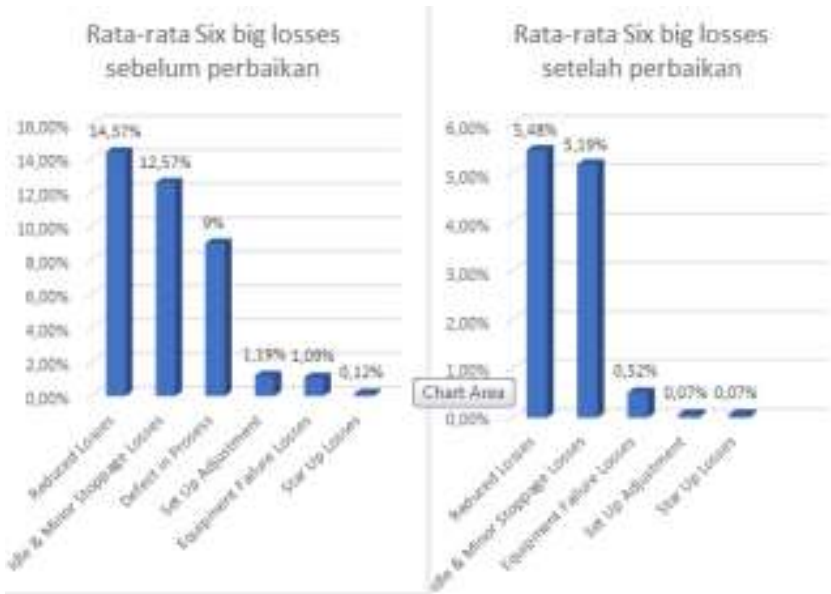

Gambar 6. Grafik Persentase six big losses setelah dan sebelum perbaikan.

Demikian juga dengan persentasi nilai six big losses juga mengalami penurun yang cukup baik hal ini bisa menjadi masukan bagi perusahaan untuk meneliti dengan menggunakan pendekatan metode OEE yang secara umum bisa untuk mengidentifikasi proses produksi terhadap salah satu mesin produksi dan juga bisa digunakan sebagai perbandingan untuk melakukan evaluasi terhadap kinerja mesin produksi di departemen yang lainnya.

\section{CONCLUSIONS}

Setelah diketahui penyebab dari nilai speed losses rendah kemudian dilakukan tindakan perbaikan dalam proses produksi yang meliputi perubahan pola kerja dan penambahan peralatan sebagai bagian dari usaha meningkat nilai OEE.

Hasil evaluasi dari proses perbaikan tersebut berhasil menaikan persentasi ketiga parameter OEE dan nilai OEE ini sendiri sampai melebihi standar OEE world class yaitu sebagai berikut: availability $98.32 \%$, performance rate $95.32 \%$, quality rate $91.55 \%$ dan nilai OEE $85.75 \%$.

Hasil perbaikan juga dapat meningkatkan nilai reduced losses yang memiliki kontribusi terbesar terhadap rendahnya nilai six big losses yang sebelumnya $14.37 \%$ menjadi $5.48 \%$, dengan demikian terjadi peningkatan sebesar $8.89 \%$ sebelum adanya perbaikan.

\section{REFERENCES}

Coyle, J.J., Bardi, E.J. and Langley Jr, C.J., 1996, The Management [1] N. C. Sakti, S. Nurjanah, and E. Rimawan, "Calculation of Overall Equipment Effectiveness Total Productive Maintenance in Improving Productivity of Casting Machines," vol. 4, no. 7, pp. 442-446, 2019.

[2] S. Saiful, A. Rapi, and O. Novawanda, "PENGUKURAN KINERJA MESIN DEFEKATOR I DENGAN MENGGUNAKAN METODE OVERALL EQUIPMENT EFFECTIVENESS(Studi Kasus pada PT. Perkebunan XY )," J. Eng. Manag. Industial Syst., vol. 2, no. 2, pp. 5-11, 2014, doi: 10.21776/ub.jemis.2014.002.02.2.

[3] Angga Adi Pratama, Miftahul Imtihan, and Suwaryo Nugroho, "Analisis Defect Pada Proses Stranding Dengan Metode Dmaic Pt. X," JENIUS J. Terap. Tek. Ind., vol. 1, no. 2, pp. 58-66, 2020, doi: 10.37373/jenius.v1i2.59.

[4] M. Imtihan and Revino, "Redesign Alat Tambahan Pada Mesin Produksi," Redesign Kompon. Otomotif Sign Alat Tambah. Pada Mesin Produksi Meningkat. Kualitas Melalui Strateg. Dmaic Bod Y Ne R Dalam, vol. 2, no. 2, pp. 56-65, 2017.

[5] A. Rozak, C. Jaqin, and H. Hasbullah, "Increasing Overall Equipment Effectiveness in Automotive Company Using DMAIC and FMEA Method," $J$. Eur. des Systèmes Autom., vol. 53, no. 1, pp. 5560, 2020, doi: 10.18280/jesa.530107. 
[6] S. N. Susianti, “Analisis Perawatan Mesin Casting Zinc Menggunakan Metode Overall Equipment Effectivness (OEE) Melalui Pendekatan DMAIC," JENIUS J. Terap. Tek. Ind., vol. 1, no. 1, pp. 3037, 2020, doi: 10.37373/jenius.v1i1.22.

[7] A. Wahid and R. Agung, "Perhitungan Total Produktifitas Maintenance (TPM) pada Mesin Bobin dengan Pendekatan Overall Equipment Effectiveness di PT. XY," J. Knowl. Ind. Eng., vol. 3, no. 3, pp. 40-49, 2016.

[8] H. H. Purba, "TPM Implementation in Automotive Component Manufacturing Companies to Analyze Efficiency Injection Machine," vol. 6, no. 4, pp. 294-313, 2020 , doi:

10.22105/jarie.2020.208271.1112. 